\title{
Peramalan Data Ekspor Nonmigas Provinsi Kalimantan Timur menggunakan Metode Weighted Fuzzy Time Series Lee
}

\author{
Muhammad Wahdeni Pramana ${ }^{(1)}$, Ika Purnamasari ${ }^{(2)}$, Surya Prangga ${ }^{(3)}$ \\ Universitas Mulawarman \\ J1. Kuaro, Gn. Kelua, Kota Samarinda, Kalimantan Timur \\ e-mail: wahdeni.pramana@gmail.com
}

\begin{abstract}
ABSTRAK
Ekspor merupakan aktivitas perdagangan atau penjualan barang dari dalam negeri ke luar negeri. Ekspor nonmigas sebagai salah satu komponen pembentuk Produk Domestik Regional Bruto (PDRB) sehingga perlu adanya suatu peramalan nilai di masa mendatang. Fuzzy Time Series (FTS) merupakan metode peramalan dengan berdasarkan teori himpunan fuzzy, logika fuzzy, serta hasil peramalan yang dapat dibahasakan (linguistik). Metode Weighted Fuzzy Time Series (WFTS) Lee merupakan perluasan dari metode FTS dengan penambahan pembobotan pada tiap pola relasi yang terbentuk. Tujuan penelitian ini adalah memperoleh nilai peramalan ekspor nonmigas Provinsi Kalimantan Timur pada bulan November 2020 serta memperoleh nilai akurasi peramalan berdasarkan metode Mean Absolute Percentage Error (MAPE) dan Root Mean Square Error (RMSE). Berdasarkan hasil analisis diperoleh nilai akurasi peramalan untuk data Ekspor Nonmigas Provinsi Kalimantan Timur bulan Januari 2019 - Oktober 2020 dengan konstanta pembobot $(c) \quad 1 \leq c \leq 2$ menggunakan metode MAPE diperoleh hasil keseluruhan dibawah $10 \%$ sehingga diperoleh konstanta pembobot terbaik yaitu $c=1$ dengan nilai MAPE terminimum yaitu sebesar 3,62\% dan RMSE minimum sebesar 50,67. Dari hasil tersebut, diperoleh hasil peramalan untuk bulan November 2020 dengan menggunakan kontanta pembobot terbaik $c=1$ yaitu sebesar 850,96 juta USD.
\end{abstract}

Kata kunci: Ekspor, MAPE, nonmigas, RMSE, WFTS Lee.

\section{ABSTRACT}

Exports is a trading and sales activity from domestic to overseas. Exports non-oil and gas as a one of component former gross regional domestic product so that its necessary to forecast a value in the future. Fuzzy Time Series (FTS) is a forecasting method based on fuzzy set theory, fuzzy logic, and the result in the form of linguistic. Weighted Fuzzy Time Series (WFTS) Lee was developed from FTS method with additions weighting in each pattern relation that is formed. This paper proposed to forecast value non-oil and gas exports in East Kalimantan Province in November 2020 and to obtain accuracy values using Mean Absolute Percentage Error (MAPE) and Root Mean Square Error (RMSE) methods. The results of this paper that obtained forecast accuracy values for data exports non-oil and gas East Kalimantan Province from Januari 2019 - Oktober 2020 with constant weighter (c) $1 \leq c \leq 2$ using MAPE as a whole below 10\% so that its obtained optimum constant weighter is $c=1$ with MAPE minimum value 3,62\% and RMSE minimum value 50,67. Of these results, the forecast value for November 2020 with optimum constant weighter $c=1$ is $\$ 850,96$ million.

Keywords: Exports, MAPE, non-oil and gas, RMSE, WFTS Lee.

\section{PENDAhUluan}

Kegiatan ekspor merupakan sebuah aktivitas perdagangan atau penjualan barang dari dalam negeri ke luar negeri. Perekonomian suatu negara tidak terlepas dari peran penting kegiatan ekspor (Nurmawaddah, S. 2019). Ekspor merupakan salah satu mesin pendorong pertumbuhan ekonomi terutama bagi negara berkembang. Pertumbuhan ekonomi suatu wilayah, dapat dilihat berdasarkan nilai Produk Domestik Regional Bruto (PDRB) yang terdiri dari komponen ekspor dan impor dari sektor migas maupun nonmigas (Ginting, A. M. 2017). Berdasarkan data BPS Prov. Kaltim, sepanjang tahun 2018 sampai 2019 nilai ekspor sektor nonmigas di wilayah Provinsi Kalimantan Timur mengalami penurunan sebesar 917,32 Juta

Muhammad Wahdeni Pramana ${ }^{1}$, Ika Purnamasari ${ }^{2}$, Surya Prangga ${ }^{3} /$

J Statistika Vol. 14, No. 1, (2021) 
US\$. Terkait hal ini, maka diperlukan adanya suatu peramalan untuk memperkirakan nilai ekspor dari sektor nonmigas di masa mendatang yang mana sektor tersebut sebagai penunjang nilai PDRB Provinsi Kalimantan Timur.

Peramalan dapat dilakukan dengan menggunakan metode statistika yang salah satunya yaitu fuzzy time series. Pada tahun 1993 Song dan Chissom memperkenalkan fuzzy time series dengan berdasarkan teori himpunan fuzzy, logika fuzzy, serta hasil peramalan yang dapat dibahasakan (linguistik). Fuzzy Time Series (FTS) senantiasa mengalami perkembangan dari waktu ke waktu. Pada tahun 2005 Hui-Kuang Yu memperkenalkan FTS dengan menggunakan panjang interval sebagai faktor dalam menghasilkan nilai peramalan yang lebih akurat dibandingkan FTS yang telah diperkenalkan oleh Song dan Chissom serta Chen. Di tahun yang sama (2005), Yu memperkenalkan kembali sebuah metode Weighted Fuzzy Time Series (WFTS) yang didalamnya terdapat pengulangan dan pembobotan yang berbeda pada tiap pola relasi yang terbentuk.

Pada tahun 2006, Cheng mengembangkan kembali WFTS dengan menggunakan data yang berpola trend sedangkan Lee tahun 2009 (Lee, M. H., Efendi, R., \& Ismail, Z. 2009). memodifikasi WFTS menggunakan bobot yang berbeda dan berdasarkan nilai tengah dari data aktual. Lee dan Suhartono pada tahun 2010 (Lee, M. H., \& Suhartono. 2010). kembali mengembangkan WFTS dengan memperhatikan urutan dari relasi yang terbentuk serta pembobotan yang baru. Hasil peramalan dengan menggunakan metode yang dikembangkan oleh Lee dan Suhartono memiliki akurasi yang lebih baik dibandingkan metode $\mathrm{Yu}$ dan Cheng.

\section{METODE PENELITIAN \\ 2.1 Peramalan}

Peramalan adalah proses memperkirakan atau menduga apa yang akan terjadi di masa mendatang berdasarkan data masa lalu maupun masa kini. Tujuan dari peramalan yaitu sebagai tindakan perventif untuk meminimalisir kejadian yang akan terjadi di masa mendatang.

Berdasarkan jangka waktunya peramalan memiliki 3 jenis yaitu:

1. Peramalan Jangka Pendek

2. Peramalan Jangka Menengah

3. Peramalan Jangka Panjang

Fuzzy time series sendiri termasuk ke dalam peramalan jangka pendek karena hanya dapat meramalkan sebanyak 1 periode ke depan. Begitu halnya dengan Weighted Fuzzy Time Series.

\subsection{Logika Fuzzy}

Logika fuzzy diperkenalkan oleh Prof. Lotfi Astor Zadeh pada tahun 1962. Logika fuzzy adalah metodologi sistem kontol pada pemecahan masalah yang cocok untuk diimplementasikan pada sistem yang sederhana, sistem kecil, dan sistem kontrol. Secara garis besar, logika fuzzy merupakan suatu cara untuk mengubah suatu pernyataan dalam bentuk linguistik menjadi nilai numerik. Logika fuzzy memungkinkan nilai keanggotaan berada di antara 0 dan 1.

Beberapa hal yang perlu diperhatikan dalam memahami logika fuzzy (Jatipaningrum, M. T. 2016) yaitu:

1. Variabel Fuzzy.

2. Himpunan Fuzzy.

3. Semesta Pembicaraan.

4. Domain Himpunan Fuzzy.

\subsection{Himpunan Fuzzy}

Menurut (Nasir, J., \& Suprianto, J. (2017). himpunan fuzzy merupakan himpunan yang mendefinisikan bahwa suatu pengamatan dapat menjadi bagian dari beberapa himpunan, dengan masing-masing bagian memiliki nilai keanggotaan yang berbeda. Suatu elemen pada himpunan fuzzy terdapat lebih dari sama dengan 2 dengan nilai keanggotaannya berada dalam rentang 0 sampai dengan 1. Himpunan fuzzy memiliki dua atribut yaitu:

1. Linguistik, yaitu penamaan suatu kelompok yang dapat mewakili suatu keadaan dengan menggunakan bahasa sehari-hari.

2. Numerik, yaitu suatu nilai atau angka yang menyatakan ukuran dari suatu variabel.

\subsection{Fuzzy Time Series}

Metode Fuzzy Time Series (FTS) merupakan salah satu metode statistika yang dapat digunakan untuk melakukan peramalan berdasarkan data masa lalu yang didalamnya termuat logika fuzzy, himpunan fuzzy, dan hasil peramalan yang dapat dibahasakan (linguistik). Proses peramalan FTS berbentuk nilai linguistik yang berasal dari bilangan real terhadap himpunan pembicaraan pada data aktual. Hal inilah yang digunakan sebagai pengganti data masa lalu yang akan diramalkan.

\subsection{Weighted Fuzzy Time Series}

Weighted Fuzzy Time Series (WFTS) merupakan perkembangan dari FTS yang didalamnya terdapat

Muhammad Wahdeni Pramana ${ }^{1}$, Ika Purnamasari ${ }^{2}$, Surya Prangga ${ }^{3} /$

J Statistika Vol. 14, No. 1, (2021) 
pengulangan dan pembobotan yang berbeda pada tiap pola relasi yang terbentuk. Pengulangan dan pembobotan merupakan dua hal yang selama ini diabaikan dalam metode FTS yang dikembangkan sebelumnya. Berikut langkah-langkah WFTS menurut Lee (2010) :

1. Mendefinisikan himpunan semesta pembicaraan $(U)$ data aktual, yang didefinisikan sebagai berikut:

$$
U=\left[X_{\min }-D_{1}, X_{\text {maks }}+D_{2}\right]
$$

dengan $X_{\text {min }}$ adalah data minimum dan $X_{\text {maks }}$ adalah data maksimum. $D_{1}$ dan $D_{2}$ adalah bilangan positif sembarang yang ditentukan oleh peneliti untuk menentukan himpunan semesta dari data aktual.

2. Membagi himpunan semesta pembicaraan $(U)$ menjadi beberapa interval dengan panjang yang sama sehingga membentuk $u_{1}, u_{2}, \ldots, u_{n}$.

3. Mendefinisikan himpunan fuzzy $A_{i}$ dari himpunan semesta berdasarkan interval partisi yang dibuat $u_{i}$ sehingga himpunan fuzzy didefinisikan sebagai berikut:

$$
\begin{aligned}
& \mu_{A_{1}}\left(u_{i}\right)=1 / u_{1}+0,5 / u_{2}+0 / u_{3}+\ldots 0 / u_{n} \\
& \mu_{A_{2}}\left(u_{i}\right)=0,5 / u_{1}+1 / u_{2}+0,5 / u_{3}+\cdots 0 / u_{n} \\
& \mu_{A_{3}}\left(u_{i}\right)=0 / u_{1}+0,5 / u_{2}+1 / u_{3}+\cdots 0 / u_{n} \\
& \begin{array}{cccccc}
\vdots & \vdots & \vdots & \vdots & \cdots & \vdots \\
\mu_{A_{n}}\left(u_{i}\right)= & 0 / u_{1}+ & 0 / u_{2}+ & 0 / u_{3}+ & \cdots & 1 / u_{n}
\end{array}
\end{aligned}
$$

dengan $\quad u_{i}$ yang mana $i=1,2, \ldots, n \quad$ adalah elemen dari himpunan semesta $(U)$ dan bilangan yang diberi simbol "/". Penentuan derajat untuk masing-masing $\mu_{A_{i}}\left(u_{i}\right)$ terhadap $A_{i}$ dengan $i=1,2, \ldots, n$ yang dimana nilainya ialah $0 ; 0,5$; atau 1.

4. Melakukan fuzzyfikasi dengan berdasarkan pendefinisian derajat keanggotaan himpunan fuzzy terhadap $A_{i}$. Pada langkah ini, proses perubahan dari nilai numerik menjadi variabel linguistik.

5. Membentuk Fuzzy Logical Relationship (FLR) berdasarkan data aktual. FLR yang terbentuk menjadi $A_{i} \rightarrow A_{j}$ yang artinya jika data ke- $t$ adalah $A_{j}$ maka $t-1$ adalah $A_{i}$ atau disebut pula $A_{i}$ adalah current state dan $A_{j}$ adalah next state.

6. Menentukan Fuzzy Logical Relationship Group (FLRG) berdasarkan FLR pada langkah ke-5 yang memiliki current state yang sama dikelompokkan dalam satu grup pada next state.
Misal $A_{1} \rightarrow A_{2}, A_{1} \rightarrow A_{5}$ maka FLRG yang terbentuk adalah $A_{1} \rightarrow A_{2}, A_{5}$.

7. Peramalan awal $F(t)$ dan defuzzifikasi $\hat{F}(t)$ dengan mengikuti aturan FTS Chen (1996) serta membentuk matriks defuzzifikasi $\mathbf{M}(t)$. Aturan pada peramalan awal dan defuzzifikasi dituliskan sebagai berikut :

\section{Aturan (i)}

Pada aturan (i) jika FLRG dari $A_{i}$ memiliki relasi menuju himpunan kosong atau dapat dituliskan $A_{i} \rightarrow \varnothing$ untuk hasil peramalan dapat diperoleh sebagai berikut :

$$
F(t)=A_{i}
$$

dengan nilai defuzzifikasi yaitu :

$$
\hat{F}(t)=m_{i}
$$

dengan $m_{i}$ merupakan nilai tengah dari interval $u_{i}$ pada derajat keanggotaan himpunan fuzzy $A_{i}$ sebagaimana Persamaan (5) sebagai berikut :

$$
m_{i}=\frac{\text { (batas atas }+ \text { batas bawah) }}{2}
$$

Selanjutnya, berdasarkan Persamaan (4) dan (5) dapat dituliskan matriks defuzzifikasi sebagai berikut :

$$
\mathbf{M}(t)=\left[m_{i}\right]
$$

\section{Aturan (ii)}

Pada aturan (ii) jika FLRG dari $A_{i}$ hanya terdapat satu FLR misalnya $A_{i} \rightarrow A_{j}$. Hasil peramalan dapat dituliskan yaitu :

$$
F(t)=A_{j}
$$

dengan nilai defuzzifikasi sebagai berikut :

$$
\hat{F}(t)=m_{j}
$$

dengan $m_{j}$ merupakan nilai tengah dari interval $u_{i}$ pada derajat keanggotaan himpunan fuzzy $A_{i}$ sebagaimana pada aturan (i) Persamaan (5). Sehingga, matriks defuzzifikasi dapat ditulis pada Persamaan (9) berikut :

$$
\mathbf{M}(t)=\left[m_{j}\right]
$$

\section{Aturan (iii)}

Pada aturan (iii) jika FLRG dari $A_{i}$ memiliki beberapa FLR $A_{i} \rightarrow A_{j_{-} 1}, A_{j_{-} 2}, \ldots, A_{j_{-}}$, maka hasil peramalannya adalah :

$$
F(t)=A_{j_{-} 1}, A_{j_{-} 2}, \ldots, A_{j_{-} p}
$$

dan untuk nilai defuzzifikasi diperoleh sebagai berikut : 


$$
\hat{F}(t)=\frac{m_{j_{-} 1}+m_{j_{-} 2}+\ldots+m_{j_{-} p}}{p}
$$

dengan $p$ adalah banyaknya FLR yang ada dan untuk mencari nilai tengah $\left(m_{j_{-} l}\right)$ untuk masing-masing FLR mengikuti Persamaan (5). Sehingga matriks defuzzifikasi untuk FLR lebih dari satu dapat dituliskan sebagai berikut:

$$
\mathbf{M}(t)=\left[m_{j_{-} 1}, m_{j_{-} 2}, \ldots, m_{j_{-} p}\right]
$$

8. Menghitung nilai pembobot berdasarkan FLRG yang terbentuk. Jika FLRG berasal dari FLR $A_{i} \rightarrow \varnothing$ dan $A_{i} \rightarrow A_{j}$ maka diberi pembobot sebesar 1, sedangkan jika FLRG yang terbentuk adalah $A_{j_{-} 1}, A_{j_{-} 2}, \ldots, A_{j_{-}}$maka pembobotnya adalah $w^{*}\left(A_{j_{-} 1}\right), w^{*}\left(A_{j_{-} 2}\right), \ldots, w^{*}\left(A_{j_{-} p}\right)$ yang mana

$$
w^{*}\left(A_{j_{-} l}\right)=\frac{w\left(A_{j_{-} l}\right)}{\sum_{l=1}^{p} w\left(A_{j_{-} l}\right)}
$$

Maka, secara umum $w\left(A_{j_{-} l}\right)$ dapat dituliskan sebagai berikut :

$$
w\left(A_{j_{-} l}\right)=\left\{\begin{array}{c}
1, \text { jika } l=1 \\
c^{l-1}, \text { jika } l>1 \text { dan } c \geq 1
\end{array}\right.
$$

Berdasarkan persamaan (14) matriks pembobot dapat ditulis :

$$
\mathbf{W}_{0}(t)=\left[\frac{1}{\sum_{l=1}^{p} w\left(A_{j_{-}}\right)}, \frac{c}{\sum_{l=1}^{p} w\left(A_{j_{-}}\right)}, \frac{c^{2}}{\sum_{l=1}^{p} w\left(A_{j_{-} l}\right)}, \ldots, \frac{c^{l-1}}{\sum_{l=1}^{p} w\left(A_{j_{-}}\right)}\right](15)
$$

9. Peramalan akhir $\hat{X}(t)$ didapatkan dengan perkalian matriks defuzzifikasi dengan matriks pembobot. Berikut rumus peramalan akhir:

$$
\hat{X}(t)=\mathbf{M}(t) \times \mathbf{W}_{o}(t)^{T}
$$

\subsection{Penentuan Panjang Interval Berbasis Rata- Rata (Average Based)}

Berikut langkah penentuan panjang interval berbasis rata-rata :

1. Menentukan panjang interval himpunan semesta pembicaraan $(U)$

$$
R=\left(X_{\text {maks }}+D_{2}\right)-\left(X_{\min }-D_{1}\right)
$$

2. Menghitung rata-rata selisih absolut setiap data

$$
S=\frac{\sum_{t=1}^{N-1}\left|\left(X_{t+1}\right)-X_{t}\right|}{N-1}
$$

3. Menghitung basis interval himpunan fuzzy

$$
B=\frac{S}{2}
$$

Dari hasil perhitungan diatas, maka disesuaikan pada tabel basis interval di bawah untuk menentukan nilai jangkauan yang akan digunakan.

Tabel 1. Basis interval

\begin{tabular}{cc}
\hline Jangkauan & Basis \\
\hline $0,1-1$ & 0,1 \\
\hline $1,1-10$ & 1 \\
\hline $11-100$ & 10 \\
\hline $101-1000$ & 100 \\
\hline $1001-10000$ & 1000 \\
\hline
\end{tabular}

4. Menghitung banyaknya himpunan fuzzy

Basis interval digunakan untuk menghitung banyaknya himpunan fuzzy. Berikut perhitungan banyaknya himpunan fuzzy :

$$
n=\frac{R}{B}
$$

5. Pembentukan himpunan fuzzy berdasarkan panjang interval berbasis rata-rata.

\subsection{Nilai Keakuratan Peramalan}

Pada penelitian ini, untuk mencari nilai keakuratan peramalan digunakan metode Mean Absolute Percentage Error (MAPE) dan Root Mean Square Error (RMSE). Peramalan dikatakan sangat akurat jika memiliki nilai MAPE di bawah $10 \%$ dan dapat dikatakan akurat jika nilainya berada di antara $10 \%$ dan $20 \%$ sedangkan RMSE dapat diartikan sebagai ukuran kesalahan yang didasarkan pada selisih antara dua buah nilai yang bersesuaian.

Rumus MAPE adalah :

$$
\text { MAPE }=\left(\frac{1}{N} \sum_{t=1}^{N}\left|\frac{X_{t}-\hat{X}(t)}{X_{t}}\right|\right) \times 100 \%(21)
$$

Rumus RMSE adalah :

$$
\mathrm{RMSE}=\sqrt{\frac{\sum_{t=1}^{N}\left(X_{t}-\bar{X}_{t}\right)^{2}}{N}}
$$

\subsection{Ekspor Nonmigas}

Ekspor adalah kegiatan perdagangan dengan cara mengirimkan barang dari dalam negeri ke luar negeri dengan memenuhi ketentuan yang berlaku. Melalui ekspor, suatu negara atau daerah dapat menghasilkan devisa yang dapat digunakan sebagai salah satu sumber dana untuk menunjang pembangunan (Fajar, I. S. 2013). Di Indonesia, ekspor terdiri dari beberapa sektor salah satunya sektor migas dan nonmigas. Ekspor migas meliputi barang yang dihasilkan dari minyak dan gas alam sedangkan ekspor nonmigas adalah barang yang

Muhammad Wahdeni Pramana ${ }^{1}$, Ika Purnamasari ${ }^{2}$, Surya Prangga ${ }^{3} /$

J Statistika Vol. 14, No. 1, (2021) 
dihasilkan selain minyak dan gas alam. Komoditas ekspor nonmigas terbagi dalam 3 sektor yaitu sektor pertanian, pertambangan, dan industri pengolahan.

\section{HASIL DAN PEMBAHASAN}

Data yang digunakan dalam penelitian ini adalah data bulanan ekspor nonmigas Provinsi Kalimantan Timur dari bulan Januari 2019 - Oktober 2020 (Badan Pusat Statistik Provinsi Kalimantan Timur. 2019). Berdasarkan data yang ada, dapat digambarkan time series plot seperti pada Gambar 1.

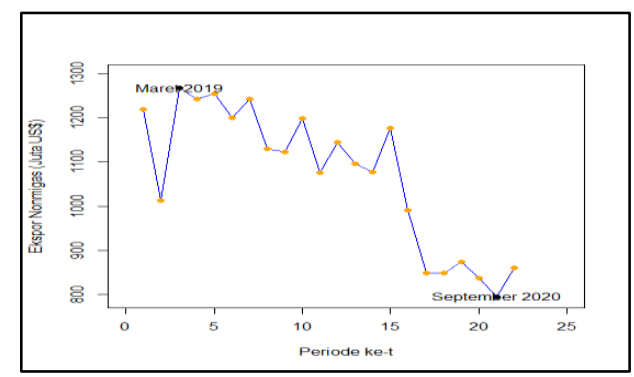

Gambar 1. Time series plot ekspor nonmigas

Berdasarkan Gambar 1 dapat dilihat bahwa nilai ekspor nonmigas di Provinsi Kalimantan Timur pada periode Januari 2019 - Oktober 2020 menunjukkan adanya fluktuasi setiap bulannya. Pada bulan Februari 2019, nilai ekspor nonmigas mengalami penurunan yang sangat tinggi dibandingkan penurunan pada bulan-bulan lain sebesar 207,2. Namun, pada bulan berikutnya yaitu bulan Maret 2019 terjadi peningkatan yang cukup drastis dibandingkan peningkatan pada bulan lainnya yaitu sebesar 256,63. Kemudian pada bulan September 2020, nilai ekspor nonmigas mencapai titik terendahnya yaitu sebesar 793,36.

\subsection{Penentuan Himpunan Semesta Pembicaraa}

Berikut himpunan semesta pembicaraan sesuai Persamaan (1) dengan $D_{1}$ dan $D_{2}$ merupakan bilangan positif sembarang. Pada penelitian ini digunakan nilai $D_{1}=2,4$ dan $D_{2}=2,39$.

$$
\begin{aligned}
U & =\left[X_{\text {min }}-D_{1} ; X_{\text {maks }}+D_{2}\right] \\
& =[793,36-2,4 ; 1.268,57+2,39] \\
& =[790,96 ; 1.270,96]
\end{aligned}
$$

3.2 Penentuan Panjang Interval Berbasis RataRata (Average Based)

Muhammad Wahdeni Pramana ${ }^{1}$, Ika Purnamasari ${ }^{2}$, Surya Prangga ${ }^{3} /$

J Statistika Vol. 14, No. 1, (2021)
Adapun perhitungan panjang interval dengan langkah sebagai berikut :

1. Menghitung panjang interval $(R)$ dari himpunan semesta pembicaraan $(U)$

Panjang interval $(R)$ ditentukan menggunakan Persamaan (17). Berikut perhitungan panjang interval $(R)$ dari semesta pembicaraan:

$$
\begin{aligned}
R & =\left(X_{\text {maks }}+D_{2}\right)-\left(X_{\min }-D_{1}\right) \\
& =(1.268,57+2,39)-(793,36-2,4) \\
& =480
\end{aligned}
$$

\begin{tabular}{|c|c|c|c|}
\hline $\begin{array}{c}\text { Tahu } \\
\text { n }\end{array}$ & Bulan & $\begin{array}{c}\text { Ekspor } \\
\text { Nonmiga } \\
\mathrm{s}\end{array}$ & $\mid X_{t}-X_{t-1}$ \\
\hline \multirow[t]{2}{*}{2019} & Januari & $1.219,14$ & - \\
\hline & Februari & $1.011,94$ & 207,2 \\
\hline$\vdots$ & $\vdots$ & $\vdots$ & $\vdots$ \\
\hline \multirow[t]{3}{*}{2020} & $\begin{array}{c}\text { Septembe } \\
\text { r }\end{array}$ & 793,36 & 42,98 \\
\hline & Oktober & 860,61 & 67,25 \\
\hline & Jumlah & & $1.647,99$ \\
\hline
\end{tabular}

2. Menghitung rata-rata selisih absolut setiap data $(S)$

Selisih absolut data aktual dapat dilihat pada Tabel 2.

Tabel 2. Selisih absolut data aktual

Berdasarkan Tabel 2 maka diperoleh jumlah selisih absolut data aktual sebesar 1.647,99. Untuk selanjutnya, dihitung nilai rata-rata selisih absolut setiap data dengan menggunakan Persamaan (18):

$$
\begin{aligned}
S & =\frac{\sum_{t=1}^{N-1}\left|X_{t}-X_{t-1}\right|}{22-1} \\
& =\frac{1.647,99}{22-1} \\
& =78,48
\end{aligned}
$$

3. Menghitung basis interval himpunan fuzzy (B)

Hasil rata-rata selisih absolut setiap data digunakan untuk menghitung basis interval fuzzy dengan menggunakan Persamaan (19). Berikut perhitungan basis interval himpunan fuzzy:

$$
\begin{aligned}
B & =\frac{S}{2} \\
& =\frac{78,48}{2} \\
& =39,24 \approx 40
\end{aligned}
$$

Berdasarkan hasil perhitungan, diperoleh nilai basis interval yaitu 39,24. Nilai basis interval tersebut, berdasarkan Tabel 1 termasuk dalam jangkauan 11- 
100 dengan basis 10. Dengan demikian, nilai interval dapat dibulatkan menjadi 40 sehingga nilai B yang digunakan selanjutnya sebesar 40 .

4. Menghitung banyaknya himpunan fuzzy (n)

Setelah diperoleh nilai basis interval sebesar 40 maka selanjutnya akan ditentukan banyaknya himpunan fuzzy berdasarkan Persamaan (20). Berikut perhitungan penentuan banyaknya himpunan fuzzy :

$$
\begin{aligned}
n & =\frac{R}{B} \\
& =\frac{480}{40} \\
& =12
\end{aligned}
$$

5. Setelah diperoleh hasil pada langkah sebelumnya, elanjutnya dapat dituliskan 12 himpunan fuzzy yang memiliki panjang interval yang sama yaitu 40. Himpunan semesta pembicaraan $(U)$ dibagi menjadi 12 himpunan yang sama panjang yaitu $u_{i}$ dengan $i=1,2, \ldots, 12$. Berikut himpunan fuzzy yang terbentuk:

$u_{1}=[790,96 ; 830,96) \quad u_{2}=[830,96 ; 870,96)$

$u_{3}=[870,96 ; 910,96) u_{4}=[910,96 ; 950,96)$

$u_{5}=[950,96 ; 990,96) \quad u_{6}=[990,96 ; 1.030,96)$

$u_{7}=[1.030,96 ; 1.070,96) \quad u_{8}=[1.070,96 ; 1.110,96)$

$u_{9}=[1.110,96 ; 1.150,96) \quad u_{10}=[1.150,96 ; 1.190,96)$

$u_{11}=[1.190,96 ; 1.230,96) \quad u_{12}=[1.230,96 ; 1.270,96]$

Setelah diperoleh himpunan fuzzy, dapat ditentukan nilai tengah untuk masing-masing himpunan fuzzy. Perhitungan nilai tengah himpunan fuzzy dilakukan dengan menggunakan Persamaan (5). Berikut hasil perhitungan nilai tengah himpunan fuzzy $\left(m_{i}\right)$ :

Tabel 3. Nilai tengah himpunan fuzzy

\begin{tabular}{cc}
\hline Fuzzy Set & $m_{i}$ \\
\hline 1 & 810,96 \\
\hline 2 & 850,96 \\
\hline$\vdots$ & $\vdots$ \\
\hline 11 & $1.210,96$ \\
\hline 12 & $1.250,96$ \\
\hline
\end{tabular}

\subsection{Pendefinisian Derajat Keanggotan Himpunan Fuzzy terhadap $\mathbf{A}_{\mathrm{i}}$}

Pendefinisian derajat keanggotaan himpunan fuzzy terhadap $A_{i}$ didasarkan pada 12 himpunan fuzzy yang terbentuk. Nilai fuzzyfikasi dari variabel linguistik data ekspor nonmigas Provinsi
Kalimantan Timur yaitu $A_{1}, A_{2}, A_{3}, \ldots, A_{12}$. Setiap himpunan fuzzy $u_{i}$ dengan $i=1,2,3, \ldots, 12$ didefinisikan terhadap $A_{i}$ dengan menggunakan Persamaan (2).

Setelah diperoleh nilai derajat keanggotaan himpunan fuzzy terhadap $A_{i}$, maka selanjutnya dapat diperoleh hasil fuzzyfikasi. Hasil fuzzyfikasi dapat dilihat pada Tabel 4.

Tabel 4. Nilai linguistik hasil fuzzyfikasi

\begin{tabular}{cc}
\hline Fuzzyfikasi & Nilai Linguistik \\
$A_{1}$ & Sangat sangat turun sekali \\
\hline$A_{2}$ & Sangat turun sekali \\
\hline$A_{3}$ & Turun sekali \\
\hline$A_{4}$ & Cukup turun \\
\hline$A_{5}$ & Turun \\
\hline$A_{6}$ & Sedikit turun \\
\hline$A_{7}$ & Sedikit naik \\
\hline$A_{8}$ & Naik \\
\hline$A_{9}$ & Cukup naik \\
\hline$A_{10}$ & Naik sekali \\
\hline$A_{11}$ & Sangat naik sekali \\
\hline$A_{12}$ & Sangat Sangat naik sekali \\
\hline
\end{tabular}

\subsection{Fuzzyfikasi Data Aktual}

Misal, bulan Januari 2019 dengan nilai ekspor nonmigas sebesar 1.219,14. Nilai tersebut termasuk ke dalam himpunan fuzzy ke-11 $\left(u_{11}\right)$ dengan interval $\quad[1.190,96 ; 1.230,96)$, sehingga bulan Januari 2019 memiliki fuzzyfikasi $A_{11}$.

Tabel 5. Fuzzyfikasi data ekspor nonmigas

\begin{tabular}{cccc}
\hline Tahun & Bulan & $\begin{array}{c}\text { Ekspor } \\
\text { Nonmigas }\end{array}$ & Fuzzyfikasi \\
\hline 2019 & Januari & $1.219,14$ & $A_{6}$ \\
\cline { 2 - 4 } & Februari & $1.011,94$ & $A_{12}$ \\
\hline$\vdots$ & $\vdots$ & $\vdots$ & $\vdots$ \\
\hline 2020 & Sept & 793,36 & $A_{1}$ \\
\cline { 2 - 4 } & Oktober & 860,61 & $A_{2}$ \\
\hline
\end{tabular}

3.5 Penentuan Fuzzy Logical Relationship (FLR)

Penentuan FLR berdasarkan current state dan next state dimana current state merupakan data pada pengamatan saat ini dan next state adalah data pengamatan selanjutnya. Misal bulan Januari 2019

Muhammad Wahdeni Pramana ${ }^{1}$, Ika Purnamasari ${ }^{2}$, Surya Prangga ${ }^{3} /$

J Statistika Vol. 14, No. 1, (2021) 

merupakan current state $\left(X_{(t-1)}\right)$ dengan nilai fuzzyfikasi $A_{11}$, dan bulan Februari 2019 merupakan next state $\left(X_{t}\right)$ dengan nilai fuzzyfikasi $A_{6}$, maka FLR yang terbentuk antara bulan Januari 2019 dengan bulan Februari 2019 adalah $A_{11} \rightarrow A_{6}$.

Tabel 6. FLR

\begin{tabular}{cc}
\hline \multicolumn{1}{c}{ Bulan } & FLR \\
\hline Januari 2019 $\rightarrow$ Februari 2019 & $A_{11} \rightarrow A_{6}$ \\
\hline Februari 2019 $\rightarrow$ Maret 2019 & $A_{6} \rightarrow A_{12}$ \\
\hline$\vdots$ & $\vdots$ \\
\hline Agustus 2020 $\rightarrow$ September 2020 & $A_{2} \rightarrow A_{1}$ \\
\hline September 2020 $\rightarrow$ Oktober 2020 & $A_{1} \rightarrow A_{2}$ \\
\hline
\end{tabular}

\subsection{Penentuan Fuzzy Logical Relationship Group} (FLRG)

FLR yang terbentuk pada Tabel 6 menunjukkan adanya current state yang sama meskipun next state yang berbeda, sehingga dapat dikelompokkan dalam satu grup yang disebut FLRG. Misal, FLR pada bulan Maret $2019 \rightarrow$ April 2019 adalah $A_{12} \rightarrow A_{12}$, begitu pula bulan April $2019 \rightarrow$ Mei 2019 adalah $A_{12} \rightarrow A_{12}$, dan bulan Mei $2019 \rightarrow$ Juni 2019 yaitu $A_{12} \rightarrow A_{11}$, serta bulan Juli $2019 \rightarrow$ Agustus 2019 memiliki FLR $A_{12} \rightarrow A_{9}$, maka FLRG yang terbentuk yaitu $A_{12} \rightarrow A_{12}, A_{12}, A_{11}, A_{9}$. FLR yang hanya memiliki satu next state ataupun menuju himpunan kosong dapat dikatakan pula sebagai FLRG.

Tabel 7. FLRG

\begin{tabular}{cc}
\hline Grup & FLRG \\
\hline 1 & $A_{1} \rightarrow A_{2}$ \\
\hline 2 & $A_{2} \rightarrow A_{2}, A_{3}, A_{1}$ \\
\hline$\vdots$ & $\vdots$ \\
\hline 12 & $A_{12} \rightarrow A_{12}, A_{12}, A_{11}, A_{9}$ \\
\hline
\end{tabular}

\subsection{Peramalan Awal dan Defuzzifikasi}

Peramalan awal $F(t)$ dan defuzzifikasi $\hat{F}(t)$ dilakukan dengan berdasarkan aturan Chen (1996). Peramalan awal adalah proses peramalan dari FLRG yang terbentuk dimana hasil peramalan yang diperoleh masih berbentuk variabel linguistik. Setelah ditentukan peramalan awal, langkah selanjutnya yaitu proses defuzzifikasi. Proses defuzzifikasi yaitu proses yang bertujuan untuk mengubah nilai peramalan yang masih berbentuk linguistik menjadi nilai numerik kembali.

Tabel 8. Peramalan awal dan defuzzifikasi

\begin{tabular}{cccc}
$\begin{array}{c}\text { Gru } \\
\mathbf{p}\end{array}$ & FLRG & $F(t)$ & $\widehat{\boldsymbol{F}}(\boldsymbol{t})$ \\
\hline 1 & $A_{1} \rightarrow A_{2}$ & $A_{2}$ & 850,96 \\
\hline 2 & $A_{2} \rightarrow A_{2}, A_{3}, A_{1}$ & $A_{2}, A_{3}, A_{1}$ & 850,96 \\
\hline$\vdots$ & $\vdots$ & $\vdots$ & $\vdots$ \\
\hline 12 & $A_{12} \rightarrow A_{12}, A_{12}, A_{11}, A_{9}$ & $A_{12}, A_{12}, A_{11}, A_{9}$ & $1.210,9$ \\
& & & 6 \\
\hline
\end{tabular}

\subsection{Pembentukan Matriks Defuzzifikasi}

Pembentukan matriks defuzzifikasi $(\mathbf{M}(t))$ didasarkan pada hasil peramalan awal dan defuzzifikasi yang telah diperoleh sebelumnya. Pembentukan matriks defuzzifikasi mengikuti aturan Chen (1996), dimana matriks defuzzifikasi merupakan matriks yang berisikan nilai tengah dari hasil peramalan awal.

Tabel 9. Matriks defuzzifikasi

\begin{tabular}{|c|c|c|}
\hline $\begin{array}{c}\text { Gru } \\
\text { p }\end{array}$ & $F(t)$ & $\mathbf{M}(t)$ \\
\hline 1 & $A_{2}$ & 850,96 \\
\hline 2 & $A_{2}, A_{3}, A_{1}$ & {$\left[\begin{array}{lll}850,96 & 890,96 & 810,96\end{array}\right]$} \\
\hline$\vdots$ & $\vdots$ & $\vdots$ \\
\hline 12 & $A_{12}, A_{12}, A_{11}, A_{9}$ & {$\left[\begin{array}{llll}1.250,96 & 1.250,96 & 1.210,96 & 1.130,96\end{array}\right]$} \\
\hline
\end{tabular}

\subsection{Perhitungan Nilai Pembobot}

Perhitungan nilai pembobot dilakukan dengan berdasarkan FLRG yang terbentuk. Jika FLRG berasal dari FLR $A_{i} \rightarrow \varnothing$ atau $A_{i} \rightarrow A_{j}$ maka diberi pembobot $\left(\mathbf{W}_{o}(t)\right)$ sebesar 1. Namun, jika FLRG yang terbentuk adalah $A_{i} \rightarrow A_{j_{-} 1}, A_{j_{-} 2}, \ldots, A_{j_{-} p}$ maka pembobot untuk masing-masing next state adalah $w^{*}\left(A_{j_{-} 1}\right), w^{*}\left(A_{j_{-} 2}\right), \ldots, w^{*}\left(A_{j_{-} p}\right) \quad$ sebagaimana pada Persamaan (13) dengan nilai konstanta pembobot $(c)$ yang digunakan yaitu $1 \leq c \leq 2$ dan jarak antar bobot sebesar 0,1 . Sebagai contoh pada FLRG dari grup ke-2 yaitu $A_{2} \rightarrow A_{2}, A_{3}, A_{1}$ maka dapat ditentukan pembobotnya ialah $w^{*}\left(A_{2}\right), w^{*}\left(A_{3}\right), w^{*}\left(A_{1}\right)$. Sebelum dilakukan perhitungan pembobot terlebih dahulu dihitung nilai

Muhammad Wahdeni Pramana ${ }^{1}$, Ika Purnamasari ${ }^{2}$, Surya Prangga ${ }^{3} /$

J Statistika Vol. 14, No. 1, (2021) 
$w\left(A_{j_{-} l}\right)$ untuk setiap next state FLRG grup ke-2 berdasarkan Persamaan (14) :

$w\left(A_{j_{-} 1}\right)=1$

$w\left(A_{j_{-} 2}\right)=c^{l-1}=c^{2-1}=c$

$w\left(A_{j_{-} 3}\right)=c^{l-1}=c^{3-1}=c^{2}$

dengan demikian, $\sum_{l=1}^{3} w\left(A_{j_{-} l}\right)=1+c+c^{2}$ sehingga

dapat diperoleh pembobot masing-masing next state berdasarkan Persamaan (13) berikut :

$w^{*}\left(A_{2}\right)=\frac{1}{\sum_{l=1}^{3} w\left(A_{j_{-} l}\right)}=\frac{1}{1+c+c^{2}}$

$w^{*}\left(A_{3}\right)=\frac{c^{l-1}}{\sum_{l=1}^{3} w\left(A_{j_{-} l}\right)}=\frac{c^{2-1}}{\sum_{l=1}^{3} w\left(A_{j_{-} l}\right)}=\frac{c}{\sum_{l=1}^{3} w\left(A_{j_{-} l}\right)}=\frac{c}{1+c+c^{2}}$

$w^{*}\left(A_{1}\right)=\frac{c^{l-1}}{\sum_{l=1}^{3} w\left(A_{j_{-} l}\right)}=\frac{c^{3-1}}{\sum_{l=1}^{3} w\left(A_{j_{-} l}\right)}=\frac{c^{2}}{\sum_{l=1}^{3} w\left(A_{j_{-} l}\right)}=\frac{c^{2}}{1+c+c^{2}}$

atau dapat dituliskan dalam matriks pembobot sebagaimana pada Persamaan (15).

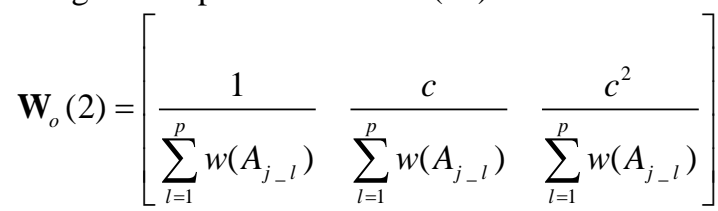

Jika $c=1$ maka dapat diperoleh nilai matriks pembobot :

$\mathbf{W}_{o}(2)=\left[\begin{array}{lll}\frac{1}{3} & \frac{1}{3} & \frac{1^{2}}{3}\end{array}\right]$

Perhitungan nilai pembobot untuk setiap kontanta pembobot (c) yang berbeda yaitu $1 \leq c \leq 2$ dan grup lainnya mengikuti seperti pada perhitungan $c=1$ pada grup ke- 2 .

Tabel 10. Nilai pembobot

\begin{tabular}{cccc}
\hline Grup & $c=1$ & $\cdots$ & $c=2$ \\
\hline 1 & 1 & $\ldots$ & 1 \\
\hline 2 & $\frac{1}{3} ; \frac{1}{3} ; \frac{1}{3}$ & $\cdots$ & $\frac{1}{7} ; \frac{2}{7} ; \frac{4}{7}$ \\
\hline$\vdots$ & $\vdots$ & $\vdots$ & $\vdots$ \\
\hline 12 & $\frac{1}{4} ; \frac{1}{4} ; \frac{1}{4} ; \frac{1}{4}$ & $\cdots$ & $\frac{1}{15} ; \frac{2}{15} ; \frac{4}{15} ; \frac{8}{15}$
\end{tabular}

\subsection{Peramalan Akhir}

Setelah mendapatkan nilai pembobot berdasarkan nilai konstanta pembobot (c) yang berbeda-beda, dan juga matriks defuzzifikasi $(\mathbf{M}(t))$, maka selanjutnya dapat dilakukan peramalan akhir yang merupakan proses akhir dari WFTS Lee (2010).

Tabel 11. Peramalan akhir

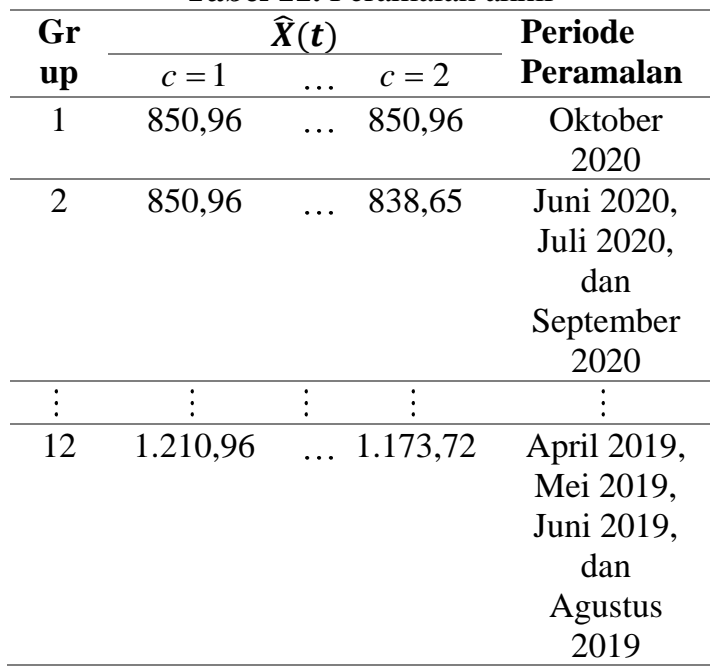

Selanjutnya, untuk memudahkan pembacaan hasil peramalan akhir maka dilakukan penyusunan berdasarkan bulan.

Tabel 12. Peramalan akhir Januari 2019 - Oktober 2020

\begin{tabular}{|c|c|c|c|c|c|}
\hline \multirow{3}{*}{$\begin{array}{c}\text { Tahu } \\
\text { n }\end{array}$} & \multirow{3}{*}{$\begin{array}{l}\text { Bul } \\
\text { an }\end{array}$} & \multirow{3}{*}{$X_{t}$} & \multirow{2}{*}{\multicolumn{3}{|c|}{$\widehat{\boldsymbol{X}}(\boldsymbol{t})$}} \\
\hline & & & & & \\
\hline & & & $c=1$ & $\ldots$ & $c=2$ \\
\hline \multirow[t]{2}{*}{2019} & Jan & $\begin{array}{c}1.219 \\
14\end{array}$ & - & . & - \\
\hline & Feb & $\begin{array}{c}1.011 \\
94\end{array}$ & $\begin{array}{c}1.117 \\
63\end{array}$ & $\cdots$ & $\begin{array}{c}1.134, \\
04\end{array}$ \\
\hline$\vdots$ & $\vdots$ & $\vdots$ & $\vdots$ & $\vdots$ & $\vdots$ \\
\hline \multirow[t]{2}{*}{2020} & Sept & 793,36 & 850,96 & $\ldots$ & 838,65 \\
\hline & Okt & 860,61 & 850,96 & $\ldots$ & 850,96 \\
\hline
\end{tabular}

Berdasarkan Tabel 12 selanjutnya dapat dihitung nilai ketepatan akurasi peramalan dengan menggunakan metode MAPE sebagaimana pada Persamaan (21) dan metode RMSE pada Persamaan (22).

Tabel 13. Nilai akurasi peramalan

\begin{tabular}{ccc}
\hline Nilai $c$ & RMSE & MAPE \\
\hline$c=1$ & 50,67 & $3,62 \%$ \\
\hline$c=1,1$ & 50,74 & $3,62 \%$ \\
\hline$\vdots$ & $\vdots$ & $\vdots$ \\
\hline$c=2$ & 53,37 & $3,82 \%$ \\
\hline
\end{tabular}

Muhammad Wahdeni Pramana ${ }^{1}$, Ika Purnamasari ${ }^{2}$, Surya Prangga ${ }^{3} /$

J Statistika Vol. 14, No. 1, (2021) 
Tabel 13 menyatakan bahwa nilai konstanta pembobot $c=1$ dan $c=1,1$ memiliki nilai akurasi MAPE yang sama yaitu sebesar 3,62\%, nilai ini lebih kecil dibanding nilai $c$ lainnya. Namun, dengan metode akurasi peramalan yang berbeda yaitu metode RMSE nilai konstanta pembobot $c=1$ memiliki nilai yang minimum dibanding nilai konstanta pembobot lainnya yaitu sebesar 50,67. Secara keseluruhan, dapat dinyatakan bahwa akurasi peramalan dari WFTS Lee untuk data ekspor Nonmigas Provinsi Kalimantan Timur dari bulan Januari 2019 - Oktober 2020 memiliki keakuratan yang sangat baik dengan kontanta pembobot terbaiknya yaitu $c=1$.

Berdasarkan hasil nilai konstanta pembobot terbaik yang telah diperoleh, maka selanjutnya dapat dilakukan peramalan untuk satu bulan ke depan yaitu bulan November 2020. Pada peramalan bulan November 2020 (sebagai next state) maka sebagai current state yaitu bulan Oktober 2020 yang terletak pada fuzzyfikasi $A_{2}$ (Tabel 5). Nilai fuzzyfikasi dari $A_{2}$ membentuk FLRG $A_{2} \rightarrow A_{2}, A_{3}, A_{1}$ dan termasuk ke dalam defuzzifikasi grup FLRG ke-2. Hasil peramalan akhir untuk grup ke-2 sebagaimana pada Tabel 11 yaitu sebesar 850,96. Sehingga, hasil peramalan bulan November 2020 adalah 850,96. Peramalan bulan November 2020 dengan nilai konstanta pembobot $(c)$ lainnya mengikuti langkah yang sama seperti pada $c=1$ dan secara lengkap dapat dilihat pada Tabel 14

Tabel 14. Hasil peramalan akhir bulan November 2020

\begin{tabular}{cc}
\hline Nilai $c$ & November 2020 \\
\hline$c=1$ & 850,96 \\
\hline$c=1,1$ & 849,59 \\
\hline$c=1,2$ & 848,2 \\
\hline$c=1,3$ & 846,81 \\
\hline$c=1,4$ & 845,46 \\
\hline$c=1,5$ & 844,17 \\
\hline$c=1,6$ & 842,93 \\
\hline$c=1,7$ & 841,77 \\
\hline$c=1,8$ & 840,67 \\
\hline$c=1,9$ & 839,63 \\
\hline$c=2$ & 838,65 \\
\hline
\end{tabular}

Berikut disajikan time series plot perbandingan hasil peramalan akhir dan data aktual ekspor Nonmigas Provinsi Kalimantan Timur bulan Januari 2019 - November 2020 dengan menggunakan metode WFTS Lee dengan nilai konstanta pembobot (c) terbaik yaitu $c=1$ dapat dilihat pada Gambar 3.

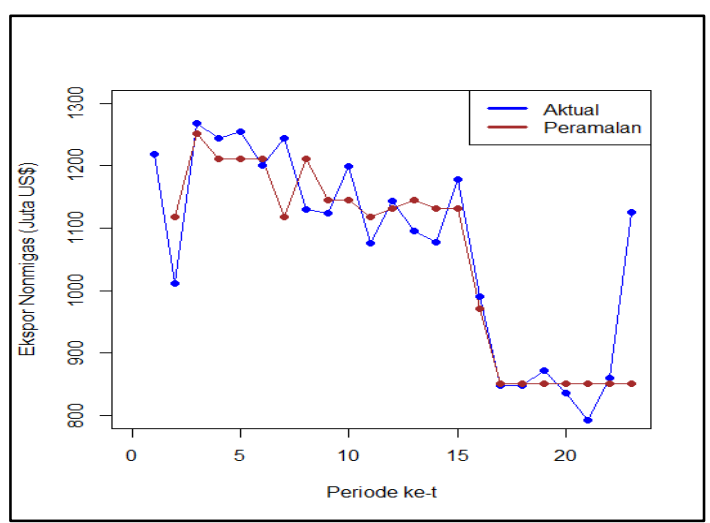

Gambar 3. Time series plot perbandingan hasil peramalan dengan data aktual

\section{KESIMPULAN}

Berdasarkan hasil dan pembahasan yang telah dilakukan, maka kesimpulan yang dapat diperoleh dari penelitian ini yaitu :

1. Hasil peramalan data ekspor nonmigas Provinsi Kalimantan Timur pada bulan November 2020 dengan menggunakan metode Weighted Fuzzy Time Series Lee (2010) dengan kontanta pembobot terbaik $c=1$ adalah sebesar 850,96.

2. Berdasarkan pembahasan dengan metode WFTS Lee diperoleh nilai akurasi peramalan dengan menggunakan metode MAPE dan metode RMSE dengan konstanta pembobot $(c)$ yaitu $1 \leq c \leq 2$ dan diperoleh nilai MAPE keseluruhan berada dibawah $10 \%$ dengan nilai minimum pada $c=1$ sebesar 3,62\% sama halnya dengan nilai RMSE memiliki nilai minimum pada $c=1$ yaitu sebesar 50,67.

\section{DAFTAR PUSTAKA}

Badan Pusat Statistik Provinsi Kalimantan Timur. (2019). Statistik Ekspor Provinsi Kalimantan Timur. Badan Pusat Statistik Provinsi Kalimantan Timur.

Fajar, I. S. (2013). Pengaruh Ekspor-Impor dan Indeks Harga Konsumen (IHK) Terhadap Pertumbuhan Ekonomi Indonesia. Jurnal Ilmiah Mahasiswa Ekonomi, Bisnis \& Manajemen.

Ginting, A. M. (2017). Analisis Pengaruh Ekspor Terhadap Pertumbuhan Ekonomi Indonesia. Buletin Ilmiah Litbang Perdagangan, 11(1), 1-

Muhammad Wahdeni Pramana ${ }^{1}$, Ika Purnamasari ${ }^{2}$, Surya Prangga ${ }^{3} /$

J Statistika Vol. 14, No. 1, (2021) 
20.

Jatipaningrum, M. T. (2016). Peramalan Data Produk Domestik Bruto dengan Fuzzy Time Series Markov Chain. Jurnal Teknologi, 9(1), 31-38.

Lee, M. H., Efendi, R., \& Ismail, Z. (2009). Modified Weighted for Enrollment Forecasting Based on Fuzzy Time Series. Matematika, 25(1),67-69

Lee, M. H., \& Suhartono. (2010). A Novel Weighted Fuzzy Time Series Model For Forecasting Seasonal Data. International Conference on Mathematical Sciences, 332-340.

Nasir, J., \& Suprianto, J. (2017). Analisis Fuzzy Logic Menentukan Pemilihan Motor Honda dengan Metode Mamdani. Jurnal Edik Informatika, 3(2), 177-187.

Nurmawaddah, S. (2019). Pengaruh Ekspor Non Migas terhadap Pertumbuhan Ekonomi Provinsi Kalimantan Timur. Akuntabel.16(1), 128-133.

Muhammad Wahdeni Pramana ${ }^{1}$, Ika Purnamasari ${ }^{2}$, Surya Prangga ${ }^{3} /$ 